\title{
Thermophysical properties of light Polemer silicat shyngisite concrete in natural conditions
}

\author{
Irina Sokolova ${ }^{1, *}$ \\ ${ }^{1}$ Moscow State University of Civil Engineering, 129337, Yaroslavskoe shosse, 26, Moscow, Russia
}

\begin{abstract}
The development of methods for protecting the structures of external walls from corrosion under the influence of the aggressive production environment is an urgent task. The author has developed lightweight polymer silicate shungizite concrete (LPSC) for external walls of buildings with acidic humid gas environments. Exterior wall structures made of this material do not need to be protected by paint and varnish coatings. The properties of LPSC were investigated. The research results showed that the proposed material in its physical and mechanical properties meets the requirements for the material of outer walls. The material has been found to be highly corrosion resistant. Previously, the author presented the results of research of thermal conductivity of LPSC for exterior walls in laboratory conditions. The results of study of temperature and humidity conditions of the wall fragment of the proposed material in natural conditions are given in this article. The studies carried out confirmed the possibility of using the material proposed by the author for the outer walls of buildings with acidic humid-gas production environments.
\end{abstract}

\section{Introduction}

Improving the durability of outer walls of industrial building with aggressive production environment is an important task [1]. Scientific research is carried out on the creation of protective coatings (secondary protection) and in the field of the creation of corrosionresistant materials that do not need additional protection against aggressive effects. This method refers to primary protection [2]. The primary protection method is more reliable and rational. The fact is that the protection of the surface of concrete structures with paint and varnish coatings must be restored at regular intervals. Works on the repair of coatings are associated with additional investments in their restoration. If the structure is made of a material that is resistant to the specified operating conditions, there is no need to use paints and varnishes. Primary protection method makes it possible to increase the resistance of building structures to operational influences. At the same time, additional expensive materials are not required at the stage of construction and operation of the structure. The author has developed a corrosion resistant material for external walls without additional protection in an acidic humid gas environment. This material combines the properties of widely known polymer silicate concrete and acid-resistant aggregates based on shungizite [34]. Polymersilicate concretes are widely used for prefabricated and monolithic reinforced and

${ }^{*}$ Corresponding author: i.socolova@yandex.ru 
unreinforced structures operating in an aggressive environment. These are various containers, trays, pit structures, floor slabs. There is an experience of using light shungizite concrete on a cement binder for external enclosing structures. However, in this area of application, such property of shungite and shungizite as high acid resistance was not taken into account. Previously the author proposed a polymer silicate lightweight concrete based on the initial components of shungizite. Fine-grained waste from shungizite gravel production is used as a finely ground filler. Studies of the physical and mechanical properties of light polymer silicate shungizite concrete (LPSC) and its resistance to atmospheric influences have been carried out. [5]. Further, the corrosion resistance of concrete and the corrosion of reinforcement in the LPSC were investigated. It was found that LPSC is an acid-resistant material. Studies have shown high corrosion resistance of reinforcement in concrete. The dependence of the thermal conductivity of the material on its density and moisture was also investigated. The results of thermal conductivity research showed the prospects of light polymer silicate schungizit concrete as the material of exterior walls from the point of view of its energy efficiency [6]. This article presents the results of thermal conductivity research of LPSC wall fragment in natural conditions.

\section{The object of the study}

The object of the study was the thermophysical properties of the outer wall of polymer silicate shungizit concrete in natural conditions. The studies were carried out to compare the results with those obtained earlier in laboratory tests. Measurements were carried out during three winter months under conditions where the external surface of the wall was exposed to the factors of the external atmosphere. The internal air temperature was $20 \pm 2{ }^{\circ} \mathrm{C}$. Humidity of internal air was $65 \pm 10 \%$. The temperature and humidity were kept constant inside the room.

Studies were conducted on a fragment of a wall. A room with a window opening was located in the basement of the building. A fragment of the wall was made of LPSC blocks and placed in the window opening. The block size was $20 \times 20 \times 35 \mathrm{~cm}$. The size of the wall fragment was $105 \times 85 \times 35 \mathrm{~cm}$. Blocks were fastened with a polymer silicate building mixture on schungizite fillers. The density of the building mixture was $1050 \mathrm{~kg} / \mathrm{m}^{3}$.To prepare the solution, shungite and shungizite components were used as a finely ground filler. The concrete composition with a density of $1030 \mathrm{~kg} / \mathrm{m}^{3}$ is shown in Table 1.The properties of LPSC with a density of $1030 \mathrm{~kg} / \mathrm{m}^{3}$ is presented in Table 2 . Data presented in this table shows that the selected concrete composition meets the requirements for a material belonging to the Primary corrosion protection group.

Table 1. Polymer silicate composition with a density of $1030 \mathrm{~kg} / \mathrm{m}^{3}$

\begin{tabular}{|l|l|}
\hline Name of components & Material consumption per $1 \mathrm{~m}^{3} / \mathrm{kg} / \mathrm{l}$ \\
\hline $\begin{array}{l}\text { shungizite gravel } \\
\text { fraction } 10-20 \mathrm{~mm}\end{array}$ & $304 / 950$ \\
\hline shungizite sand & \\
fraction $0,15-2,5$ & $187 / 155$ \\
fraction $0,15-5,0$ & $184 / 265$ \\
\hline shungizite finely ground filler & $190 / 220$ \\
\hline liquid glass with a density of $1,38 \mathrm{~g} / \mathrm{cm}^{3}$ & $284 / 205$ \\
\hline furyl alcohol & $8.5 / 7.6$ \\
\hline sodium fluorosilicate & $42.5 / 41.5$ \\
\hline total material consumption & $1200 / 1845$ \\
\hline
\end{tabular}

Table 2. Properties of the Polymer silicate composition with a density of $1030 \mathrm{~kg} / \mathrm{m}^{3}$ 


\begin{tabular}{|l|l|}
\hline Properties & values of indicators \\
\hline dry material density, $\mathrm{Kg} / \mathrm{m}^{3}$ & 1030 \\
\hline compressive strength, $\mathrm{MPa}$ & 13.0 \\
\hline open capillary pore volume, $\%$ & 10.0 \\
\hline pore saturation factor, $\%$ & 16.7 \\
\hline volume of conditionally closed pores, $\%$ & 47.8 \\
\hline concrete microporosity index, \% & 87.0 \\
\hline intergranular voidness, $\%$ & 2.2 \\
\hline water absorption, $\%$ & 10.0 \\
\hline $\begin{array}{l}\text { sorption humidity, } \% \text { at a relative humidity of } \\
80 \%\end{array}$ & 2.15 \\
\hline $\begin{array}{l}\text { water resistance coefficient (test period - 360 } \\
\text { days) }\end{array}$ & 0.83 \\
\hline weather resistance (test period - 360 days) & 0.94 \\
\hline frost resistance & $\mathrm{F} 75$ \\
\hline $\begin{array}{l}\text { chemical resistance coefficient in } 24 \% \mathrm{H}_{2} \mathrm{SO}_{4} \text { (test } \\
\text { period - 360 days) }\end{array}$ & 0.94 \\
\hline $\begin{array}{l}\text { dry heat conductivity coefficient, } \\
\text { W / (m }{ }^{\circ} \mathrm{C} \text { ). }\end{array}$ & 0.26 \\
\hline
\end{tabular}

Thermocouples were placed on the outer and inner surfaces and at equal distances within the sample. Heat fluxes were measured by heat meters. Heat meter readings were taken with digital voltmeters. The layout of the temperature sensors and heat meters is shown in Figure 1.

During the study, the temperatures of the internal and external air, the temperatures of the internal and external surfaces of the wall fragment were recorded. The temperatures inside the sample were measured over five sections located at a distance of $70 \mathrm{~mm}$ from each other and from the surfaces of the wall fragment. The readings of the measured and actual heat flux passing through the fence were taken.

In addition, the moisture content was determined along the wall thickness at the end of the moisture accumulation period. For this purpose, in certain areas along the wall thickness, test samples of the material were taken.

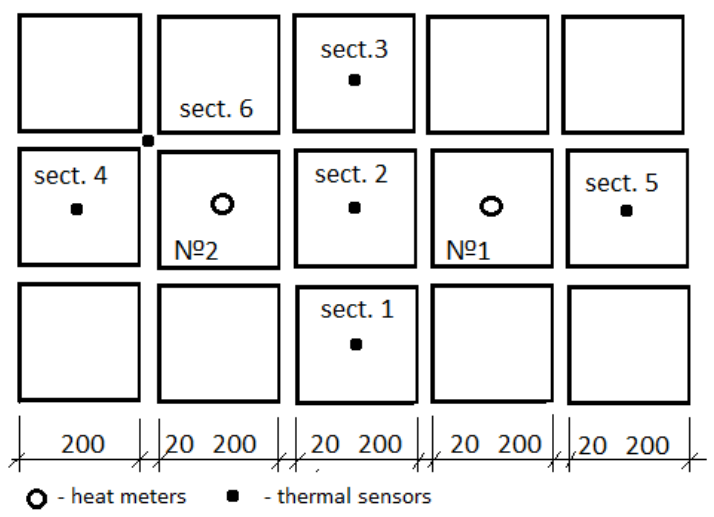

Fig. 1. The layout of the temperature sensors and heat meters 


\section{Results}

The temperature distribution in the studied sections and humidity over the wall thickness at the end of the moisture accumulation period is shown in Figure 2 .
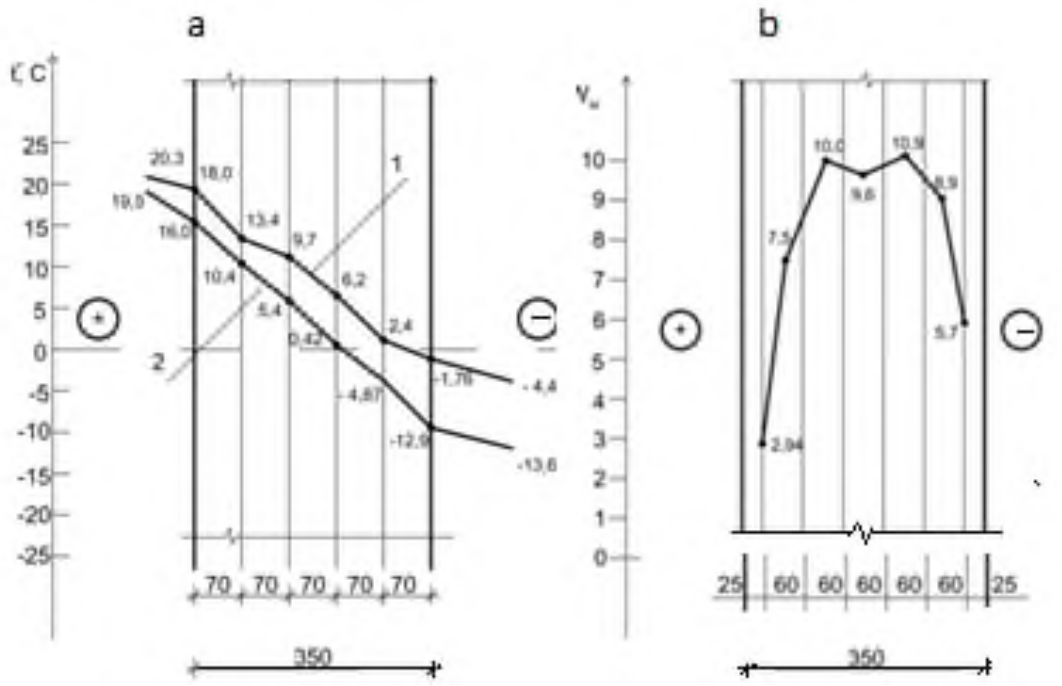

Fig. 2. The temperature distribution in the studied sections and humidity over the wall thickness at the end of the moisture accumulation period: $\mathrm{a}$ - temperature distribution; $\mathrm{b}$ - humidity over the wall thickness

Heat transfer coefficiens on the fragment surface during the test period: a) on the inner surface $\alpha_{\mathrm{w}}=9.13 \mathrm{~W} /\left(\mathrm{m}^{2}{ }^{\circ} \mathrm{C}\right)$ and on the outer surface $\alpha_{\mathrm{n}}=11.02 \mathrm{~W} /\left(\mathrm{m}^{2}{ }^{\circ} \mathrm{C}\right)$. The average value of the coefficient of thermal conductivity of the masonry at an average humidity of concrete of $7.8 \%$ was equal to $\lambda=0.42 \mathrm{~W} /\left(\mathrm{m}{ }^{\circ} \mathrm{C}\right)$. The heat transfer resistance of a wall of blocks with a thickness of $35 \mathrm{~cm}$ at standard values of resistance to heat perception was Ro $=1.0\left(\mathrm{~m}^{2}{ }^{\circ} \mathrm{C}\right) / \mathrm{W}$. To assess the reliability of the results of thermophysical tests of a wall fragment, the coefficient of thermal conductivity of the block masonry was determined.

The coefficient of thermal conductivity was determined by the formula:

$$
\lambda \mathrm{av}=\frac{\lambda 1 v 1+\lambda 1 v 2}{v 1+v 2}
$$

where:

$\lambda_{\mathrm{av}}-$ average thermal conductivity coefficient of the sample, $\mathrm{BT} /\left(\mathrm{M}{ }^{\circ} \mathrm{C}\right)$,

$\lambda_{1}$ - thermal conductivity coefficient of concrete with density $1030 \mathrm{~kg} / \mathrm{m}^{3}, \lambda_{1}=0,36 \mathrm{wt} /(\mathrm{M}$ ${ }^{\circ} \mathrm{C}$ ),

$\lambda_{2}$ - thermal conductivity coefficient of polymer silicate building mixture with a density of $1550 \mathrm{~kg} / \mathrm{m}^{3}$ equal $0.76 \mathrm{wt} /\left(\mathrm{M}^{\circ} \mathrm{C}\right), \lambda_{2}=0.76 \mathrm{wt} /\left(\mathrm{M}^{\circ} \mathrm{C}\right)$;

$\mathrm{v}_{1}$ and $\mathrm{v}_{2}$ - volumes occupied respectively by concrete and building mixture, $\%$. The volume of the entire sample is taken as $100 \%$.

The volume occupied by the mortar in the masonry is $15 \%$.

Under these conditions, the coefficient of thermal conductivity of the masonry, determined by formula 1 is 


$$
\lambda_{\mathrm{av}}=\frac{0,36 \cdot 85+0,76 \cdot 15}{100}=0.42 \mathrm{~W} /\left(\mathrm{m}{ }^{\circ} \mathrm{C}\right) .
$$

The maximum permissible increment of the calculated mass ratio of moisture in the material for lightweight concrete (including shungizite concrete) on porous aggregates is 5\%. The calculated mass ratio of moisture in LPSC with a density of $1030 \mathrm{~kg} / \mathrm{m}^{3}$ is $10 \%$ (for operating conditions of group B) [5]. The maximum permissible humidity at the end of the moisture accumulation period is $15 \%$. The actual moisture content of concrete at the end of the moisture accumulation period was $7.85 \%$. Therefore, it can be concluded that the polymersilicate shungizite concrete meets the regulatory requirements for humidity conditions.

\section{Conclusions}

The results of studies of the wall fragment of the lightweight polymer silicate shungizite concrete in natural winter conditions confirmed the results of laboratory experiments. All the results obtained allow us to conclude that lightweight polymer silicate shungizite concretes developed and researched by the author is suitable for the outer walls of industrial buildings with acidic humid-gas operating environments without additional protection of them with acid-resistant paint and varnish coatings. In terms of its physical, mechanical and thermophysical properties, LPSC also meets the requirements for the material of the protective and decorative layer of the outer walls. Studies have shown that the material developed by the author can be classified as chemically resistant, structural and heatinsulating, with decorative properties. The comprehensive studies of LPSC allow us to determine the following areas of application of the material for operating conditions in acidic humid-gas aggressive environments: exterior walls in new construction; insulating layers of external walls during renovation; replacement of damaged wall sections; installation of partitions inside the building; cladding of sections of walls in order to protect them against corrosion. This material makes full use of the properties of shungizite as a light acid-resistant filler. The use of shungite fillers - wastes from the production of shungizite gravel will have a positive effect on the environment.

\section{References}

1. E. N. Hahaleva, Sh. M. Rahimbaev, N. M. Tolypina, Povyshenie korrozionnoj stojkosti betonnyh konstrukcij promyshlennyh predpriyatij. Belgorod: Belgorodskij gosudarstvennyj tekhnologicheskij universitet im., 84 (2016)

2. A. S. Myagkih, Tekhnologii i metody pervichnoj zashchity betona dlya naruzhnyh sten zdanij na stadii proektnyh rabot, Novye tekhnologii neftegazovomu region, 71-73 (Tyumen': Tyumenskij industrial'nyj universitet, 2019)

3. M. M. Filippov, Shungitosoderzhashchie slancy Karelii - cennoe syr'e dlya stroitel'noj industrii Rossii, Gornyj zhurnal, 5, 7-8 (2012)

4. O. V. Myasnikova, A. B. Pervunina, Perspektivy kompleksnogo ispol'zovaniya nizkouglerodistyh porod Karelii, Gornyj zhurnal., 3, 78-82 (2019)

5. I. V. Sokolova, Povyshenie dolgovechnosti naruzhnyh sten zdanij tekstil'noj promyshlennosti metodom pervichnoj zashchity, Izvestiya vysshih uchebnyh zavedenij. Tekhnologiya tekstil'noj promyshlennosti, 4(370), 258-262 (2017)

6. I. Sokolova, Energy efficiency of external walls of buildings with aggressive production environments, 02038 Published online: 02 April 2019 DOI: https://doi.org/10.1051/e3sconf/20199102038 
7. I. Ilin, V. Vasilenok, R. Marchenko, Use of renewable energy and tax burden on CO2 emissions in industrial enterprises, E3S Web of Conferences, 110, 0210 (2019)

8. S. Kalyazina, A. Borremans, A. Dubgorn, Participation of citizens in sustainable development of big cities, MATEC Web of Conferences, 193, 01029 (2018) 